\title{
Toward Optimization of Wood Industry Wastewater Treatment in Microbial Fuel Cells-Mixed Wastewaters Approach
}

\author{
Monika Kloch and Renata Toczyłowska-Mamińska * \\ Institute of Biology, Department of Physics and Biophysics, Warsaw University of Life Sciences-SGGW, \\ 159 Nowoursynowska St., 02-776 Warsaw, Poland; monika_kloch@sggw.pl \\ * Correspondence: renata_toczylowska@sggw.pl
}

Received: 29 November 2019; Accepted: 3 January 2020; Published: 5 January 2020

\begin{abstract}
Microbial fuel cell (MFC) has the potential to become a promising sustainable technology of wastewater treatment. Usually, the investigations on MFCs are aimed at maximized power production in the system. In this article, we focused on the optimization of wood industry wastewater treatment in MFC, in combination with municipal wastewater as a source of microorganisms. We investigated the influence of different external resistance $(2000 \Omega, 1000 \Omega, 500 \Omega$, and $100 \Omega$ ) on power density and wastewater treatment efficiency (chemical oxygen demand (COD) removal) in 1-month MFC operation time. We found that the highest COD removal was for MFCs under $R=1000 \Omega$ after 22 days of MFC operation, while the highest current density was obtained for the lowest applied resistance. The results imply that wastewater treatment parameters such as resistance and time of MFC operation should be a subject of optimization for each specific type of wastewater used, in order to maximize either wastewater treatment efficiency or power production in MFC. Thus, optimization of power production and COD removal efficiency in MFCs need to be run separately as different resistances are required for maximizing these two parameters. When COD removal efficiency is a subject of optimization, there is no universal value of external resistance, but it should be set to the specific wastewater characteristics.
\end{abstract}

Keywords: microbial fuel cell; wastewater treatment; wood industry wastewater

\section{Introduction}

Microbial fuel cell technology (MFC) enables sustainable treatment of various wastewaters, e.g., domestic [1], brewery [2], distillery [3], hospital [4], pharmaceutical [5], paper [6], wine [7], sewage sludge [8], mine drainage wastewater [9], or pulping wastewater [10]. Due to the presence of microorganisms with different metabolism (fermenters, methanogens, or electrogens), it is possible to decompose organic matter present in wastewater into simpler compounds that are used by electrogenic species for current production (Figure 1). An obvious gain from the MFC technology application is current produced in the system, but equally valuable is effective wastewater treatment that accompanies current production. Application of MFCs to wastewater treatment allowed not only for organic matter removal (measured by chemical oxygen demand-COD removal efficiency) but also for reducing content of nitrogen, phosphorus, and various, often toxic, metals (e.g., $\mathrm{Cr}, \mathrm{Cu}, \mathrm{Fe}, \mathrm{Co}$ ) in wastewater [11-14]. In case of some wastewaters, COD or metal removal efficiencies exceeded $90 \%$ what enables direct reuse of the MFC-treated water [15]. 


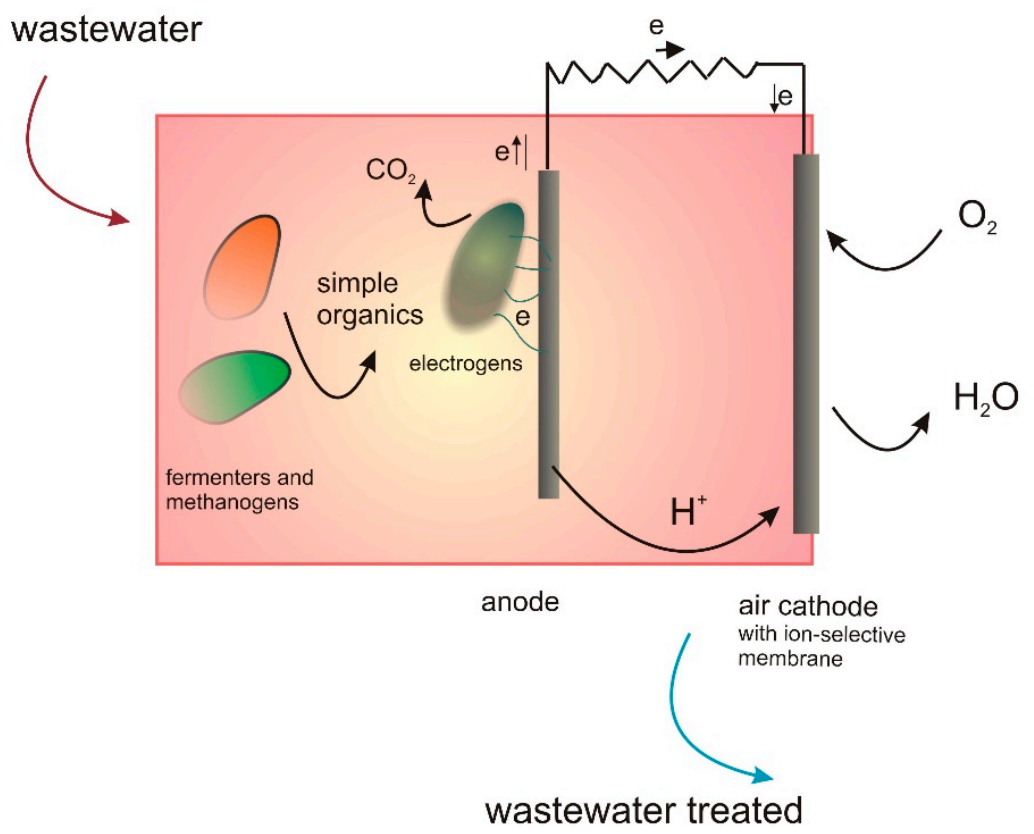

Figure 1. Schematic presentation of wastewater treatment accompanied by current production in air cathode single-chamber microbial fuel cell (MFC).

Though various industrial wastewaters were treated in MFCs, wood industry wastewater has been ignored as this sector is commonly thought of as environmentally benign and based on sustainable substrate-wood. Meanwhile, the plants producing wood-based panels (e.g., OSB—oriented strand board, $\mathrm{PB}$ - particleboard, MDF-medium density fiberboard) use between 0.1 and $1.5 \mathrm{~m}^{3}$ of water per $1 \mathrm{~m}^{3}$ of panel produced [16]. According to the Food and Agriculture Organization of the United Nations, global production of wood-based panels reached $416 \mathrm{mln} \mathrm{m}^{3}$ in 2016, which is a $24 \%$ increase compared to 2012 [17]. Thus, we can estimate that the global wood-based panel industry can generate up to ca. $600 \mathrm{mln} \mathrm{m}^{3}$ of wastewater every year. Using MFC technology would allow to treat wood industry wastewater in situ and reuse treated water in the producing plant. This approach reduces high costs of treatment of high-COD wastewater and decreases water consumption in the plant.

As much attention is paid to maximizing power production in MFCs, a lot is known about factors influencing power production in these systems. Power produced is dependent on the reactor geometry, surface area of anode and cathode (doubling cathode area can increase power production by $62 \%$, but doubling anode area increases power only by $12 \%$ ) [18], solution conductivity (the higher solution conductivity, the higher power produced), or COD load [15]. However, much less we know about factors that influence wastewater treatment efficiency. An exception is the hydraulic retention time, which seems to be the key parameter influencing wastewater treatment efficiency in the MFC of fixed architecture [19]. External resistance is a very important parameter that affects the amount of current produced in the system as it drives anode potential and influences the competition between electrogenic and non-electrogenic species $[20,21]$. However, the influence of external resistance on wastewater treatment efficiency and power production is not clear as discrepant results were obtained for various wastewaters (Table 1). Lyon et al. investigated domestic wastewater-fed MFCs where microbial community structure changed with external resistance so that the power was produced on a comparable level [22]. Applied various external resistances had no influence on maximum power and current produced in the reactors [22]. In MFC fed mixed wastewaters (brewery and domestic), external resistance had slight influence on power production, but the highest current was produced for the lowest applied resistance [23]. Simultaneously, the highest COD removal efficiency was observed for the highest external resistance. Zhang et al. reported that lowering external resistance resulted in an enhanced sulfide and vanadium removal rate in sulfide-rich wastewater [24]. The investigations showed 
$40 \%$ increase in $\mathrm{V}^{5+}$ reduction between the highest and the lowest resistance tested. An opposite effect was observed for cellulose degradation-increasing external resistance caused increase of cellulose degradation, which was a result of changing microorganisms' metabolism [21]. In another work, changing MFC external resistance in wide range from $2 \Omega$ to $5000 \Omega$ had no influence on COD removal efficiency [25].

In this work, we investigated the influence of different external resistance on wood industry wastewater treatment efficiency throughout MFC operation. The results of the investigations are needed for optimization of the procedures for wood industry wastewater treatment in MFC technology.

Table 1. Influence of external resistance on wastewater treatment efficiency and power production in MFCs fed various types of wastewater.

\begin{tabular}{|c|c|c|c|c|c|}
\hline Wastewater Type & MFC Type & Power Density & Current Density & Wastewater Treatment Efficiency & Reference \\
\hline distillery wastewater & dual chamber & $\begin{array}{c}\mathrm{R}=5000 \Omega ; 280 \mathrm{~mW} / \mathrm{m}^{2} \\
\mathrm{R}=100 \Omega ; 25 \mathrm{~mW} / \mathrm{m}^{2}\end{array}$ & $\begin{array}{c}\mathrm{R}=5000 \Omega ; 5.9 \mathrm{~mA} / \mathrm{m}^{2} \\
\mathrm{R}=100 \Omega ; 53 \mathrm{~mA} / \mathrm{m}^{2}\end{array}$ & not investigated & [26] \\
\hline $\begin{array}{c}\text { brewery } \\
\text { wastewater:domestic } \\
\text { wastewater (1:100) }\end{array}$ & dual chamber & $\begin{array}{c}\mathrm{R}=50 \mathrm{k} \Omega ;<3 \mathrm{~mW} / \mathrm{m}^{2} \\
\mathrm{R}=25 \mathrm{k} \Omega ; \text { ca. } 3 \mathrm{~mW} / \mathrm{m}^{2} \\
\mathrm{R}=10 \mathrm{k} \Omega ; \text { ca. } 3 \mathrm{~mW} / \mathrm{m}^{2} \\
\mathrm{R}=1 \mathrm{k} \Omega ; \text { ca. } 10 \mathrm{~mW} / \mathrm{m}^{2} \\
\mathrm{R}=100 \Omega ; 3 \mathrm{~mW} / \mathrm{m}^{2}\end{array}$ & $\begin{array}{l}\mathrm{R}=50 \mathrm{k} \Omega ; 8 \mathrm{~mA} / \mathrm{m}^{2} \\
\mathrm{R}=25 \mathrm{k} \Omega ; 13 \mathrm{~mA} / \mathrm{m}^{2} \\
\mathrm{R}=10 \mathrm{k} \Omega ; 25 \mathrm{~mA} / \mathrm{m}^{2} \\
\mathrm{R}=1 \mathrm{k} \Omega, 130 \mathrm{~mA} / \mathrm{m}^{2} \\
\mathrm{R}=100 \Omega ; 274 \mathrm{~mA} / \mathrm{m}^{2}\end{array}$ & $\begin{array}{l}\mathrm{R}=50 \mathrm{k} \Omega ; \Delta \mathrm{COD}=60 \% \\
\mathrm{R}=25 \mathrm{k} \Omega ; \Delta \mathrm{COD}=85 \% \\
\mathrm{R}=10 \mathrm{k} \Omega ; \Delta \mathrm{COD}=87 \% \\
\mathrm{R}=10 \mathrm{k} \Omega ; \Delta \mathrm{COD}=88 \% \\
\mathrm{R}=0.1 \mathrm{k} \Omega, \Delta \mathrm{COD}=92 \%\end{array}$ & [23] \\
\hline $\begin{array}{l}\text { domestic wastewater fed } \\
\text { acetate }\end{array}$ & single chamber & $\begin{array}{l}\text { R from } 10 \Omega \text { to } 10 \mathrm{k} \Omega \text {, ca. } \\
30 \mathrm{~mW} / \mathrm{m}^{2} \text { for all } \\
\text { applied resistances }\end{array}$ & $\begin{array}{l}\mathrm{R} \text { from } 10 \Omega \text { to } 1000 \Omega, \\
\text { ca. } 150 \mathrm{~mA} / \mathrm{m}^{2} \text { for all } \\
\text { applied resistances }\end{array}$ & not investigated & [22] \\
\hline high sulfide wastewater & dual chamber & not investigated & not investigated & $\begin{array}{c}\mathrm{V}^{4+} \text { increased from } 116.2 \text { to } 177.3 \\
\mathrm{mg} / \mathrm{L} \text { when } \mathrm{R} \text { decreased from } 1000 \\
\Omega \text { to } 50 \Omega\end{array}$ & [24] \\
\hline $\begin{array}{l}\text { malodorous surface } \\
\text { water }\end{array}$ & single chamber & not investigated & not investigated & $\begin{array}{l}\mathrm{R}=2 \Omega ; \mathrm{R}=30 \Omega ; \mathrm{R}=5000 \Omega ; \\
\text { maximum } \Delta \mathrm{COD}=86 \% \text { for all } \\
\text { tested resistances }\end{array}$ & [25] \\
\hline artificial brackish water & dual chamber & not investigated & $\begin{array}{c}\mathrm{R}=10 \Omega ; 1.65 \mathrm{~mA} / \mathrm{m}^{2} \\
\mathrm{R}=100 \Omega ; 1.75 \mathrm{~mA} / \mathrm{m}^{2} \\
\mathrm{R}=188 \Omega ; 0.8 \mathrm{~mA} / \mathrm{m}^{2} \\
\mathrm{R}=1875 \Omega ; 0.3 \mathrm{~mA} / \mathrm{m}^{2} \\
\mathrm{R}=4690 \Omega ; 0.1 \mathrm{~mA} / \mathrm{m}^{2}\end{array}$ & $\begin{array}{l}\text { no influence of external resistance } \\
\text { on COD removal (maximum } \\
\Delta \mathrm{COD}=30 \% \text { vs control) }\end{array}$ & [27] \\
\hline synthetic wastewater & dual chamber & $\begin{array}{l}\mathrm{R} \text { from } 5 \Omega \text { to } 200 \Omega \text {; } \\
\text { maximum } 170 \mathrm{~mW} / \mathrm{m}^{2} \\
\quad \text { for } \mathrm{R}=50 \Omega\end{array}$ & $\begin{array}{l}\mathrm{R} \text { from } 5 \Omega \text { to } 200 \Omega \text {; } \\
\text { maximum current } 1.8 \\
\mathrm{~A} / \mathrm{m}^{2} \text { for } \mathrm{R}=5 \Omega\end{array}$ & $\begin{array}{c}\mathrm{R} \text { from } 5 \Omega \text { to } 200 \Omega ; \\
\text { maximum nitrate removal rate for } \\
R=10 \Omega\left(54.80 \pm 0.01 \mathrm{gm}^{-3} \mathrm{~d}^{-1}\right)\end{array}$ & [28] \\
\hline wine wastewater & dual chamber & $\begin{array}{l}\mathrm{R}=600 \Omega ; 191 \mathrm{~mW} / \mathrm{m}^{2} \\
\mathrm{R}=900 \Omega ; 80 \mathrm{~mW} / \mathrm{m}^{2} \\
\mathrm{R}=1400 \Omega ; 40 \mathrm{~mW} / \mathrm{m}^{2}\end{array}$ & $\begin{array}{l}\mathrm{R}=600 \Omega ; 360 \mathrm{~mA} / \mathrm{m}^{2} \\
\mathrm{R}=900 \Omega ; 203 \mathrm{~mA} / \mathrm{m}^{2} \\
\mathrm{R}=1400 \Omega ; 112 \mathrm{~mA} / \mathrm{m}^{2}\end{array}$ & $\begin{array}{l}\mathrm{R}=600 \Omega ; \Delta \mathrm{COD}=59 \% \\
\mathrm{R}=900 \Omega ; \Delta \mathrm{COD}=41 \% \\
\mathrm{R}=1400 \Omega ; \Delta \mathrm{COD}=50 \%\end{array}$ & [7] \\
\hline $\begin{array}{c}\text { wood industry } \\
\text { wastewater:domestic } \\
\text { wastewater (1:1) }\end{array}$ & single chamber & $\begin{array}{c}\mathrm{R}=100 \Omega ; 14 \mathrm{~mW} / \mathrm{m}^{2} \\
\mathrm{R}=500 \Omega ; 25 \mathrm{~mW} / \mathrm{m}^{2} \\
\mathrm{R}=1000 \Omega ; 112 \mathrm{~mW} / \mathrm{m}^{2} \\
\mathrm{R}=2000 \Omega ; 175 \mathrm{~mW} / \mathrm{m}^{2}\end{array}$ & $\begin{array}{l}\mathrm{R}=100 \Omega ; 443 \mathrm{~mA} / \mathrm{m}^{2} \\
\mathrm{R}=500 \Omega ; 269 \mathrm{~mA} / \mathrm{m}^{2} \\
\mathrm{R}=1000 \Omega ; 400 \mathrm{~mA} / \mathrm{m}^{2} \\
\mathrm{R}=2000 \Omega ; 354 \mathrm{~mA} / \mathrm{m}^{2}\end{array}$ & $\begin{array}{l}\mathrm{R}=100 \Omega ; \Delta \mathrm{COD}=66 \% \\
\mathrm{R}=500 \Omega ; \Delta \mathrm{COD}=65 \% \\
\mathrm{R}=1000 \Omega ; \Delta \mathrm{COD}=94 \% \\
\mathrm{R}=2000 \Omega ; \Delta \mathrm{COD}=80 \%\end{array}$ & this work \\
\hline
\end{tabular}

\section{Materials and Methods}

\subsection{MFC Construction and Operation}

In all experiments, single-chamber MFCs prepared according to the design described by Logan et al. were used [29]. The MFCs volume was $28 \mathrm{~mL}$, and anode was carbon fiber brush $(2 \mathrm{~cm}$ long, $2.5 \mathrm{~cm}$ in diameter) and air cathode (of $7 \mathrm{~cm}^{2}$ area). The cathodes were made of carbon paper with four PTFE diffusion layer, $\mathrm{Pt}$ as catalyst, and Nafion as a binder as described earlier [30]. The mixture of 1:1 v/v wood hydrothermal wastewater (WHTW) with municipal wastewater in $50 \mathrm{mM}$ phosphate-buffered saline (PBS) was added to the MFC. WHTW was collected from the basin for wood hydrothermal treatment at $65{ }^{\circ} \mathrm{C}$ in a plywood manufacturing plant. The wastewaters were used as the source of bacteria and substrate without additional supplementation. MFCs were operated in fed-batch mode at $37^{\circ} \mathrm{C}$ under various external load: $2000 \Omega, 1000 \Omega, 500 \Omega$, and $100 \Omega$. MFC fed WHTW in $50 \mathrm{mM}$ PBS under constant $R=1000 \Omega$ was used as the control. The solution was changed when voltage dropped below $50 \mathrm{mV}$ [31]. When the solution was replaced, ca. $5 \mathrm{~mL}$ of solution was left in reactors for the next cycle of treatment. Current and power production were determined by measuring voltage (V) every 20 min across applied external resistance with the use of automated measuring system connected with a computer. Current $(\mathrm{I})$ was calculated from Ohm's law $(\mathrm{I}=\mathrm{V} / \mathrm{R})$, and power $(\mathrm{P})$ was calculated as 
$\mathrm{P}=\mathrm{IV}$. The current density and power density were normalized to the projected surface area of the cathode. The maximum current and power values were calculated from voltage peaks.

\subsection{Chemical Characteristics of Wastewater and COD Removal Efficiency Determination}

Fe was determined colorimetrically [32], and determination of chlorides was made with the use of potentiometric chloride ion-selective electrode. Determination of the amount of suspension was made according to standard method PN-72/C-04559 [33]. Determination of solids was made according to standard method PN-75/C-04541 [34]. Wastewater conductivity was measured by ELMETRON CC-105 conductivity meter.

The COD was determined by dichromate method that measured the oxygen equivalent of the amount of organic substances oxidized by potassium dichromate in a concentrated sulphuric acid solution [35]. Silver nitrate was added as a catalyst, and mercury sulfate was added to reduce interferences from the oxidation of chloride ions by dichromate.

The efficiency of the chemical oxygen demand removal $(\triangle \mathrm{COD})$ was calculated from the formula:

$$
\Delta \mathrm{COD}=\frac{\mathrm{CODo}-\mathrm{COD}_{\mathrm{t}}}{\mathrm{COD}_{0}} \times 100 \%
$$

where $\mathrm{COD}_{\mathrm{o}}$ is the initial $\mathrm{COD}$, and $\mathrm{COD}_{\mathrm{t}}$ is the $\mathrm{COD}$ after time $\mathrm{t}$.

The coulombic efficiency (CE) was calculated from the equation:

$$
C E=\frac{M \int_{0}^{t} I d t}{\operatorname{nvF}\left(C_{0}-C O D_{t}\right)}
$$

where $\mathrm{M}$ is the molecular weight of oxygen, $\mathrm{I}$ is current, $\mathrm{F}$ is Faraday's constant, $\mathrm{n}$ is 4 - the number of electrons exchanged per mole of oxygen, and $\mathrm{v}$ is the anolyte volume.

\section{Results and Discussion}

\subsection{Influence of External Resistance on Current Production in MFCs}

WHTW is one of the wastewaters generated in plywood production during wood hydrothermal treatment. The chemical composition of WHTW differs between particular plants as is dependent on wood hydrothermal treatment nexus, e.g., wood species used, temperature, time of wood treatment, or frequency of changing water in the basin [36]. Generally, WHTW is acidic (pH usually ca. 5), highly polluted wastewater with COD ranging from $3000 \mathrm{mg} / \mathrm{L}$ to even above 11,000 mg/L. It contains products of wood hydrolysis as well as those extracted from wood, celluloses, hemicelluloses, and lignin. In these investigations, we used wastewater sampled from a basin where beech wood was treated hydrothermally at $65{ }^{\circ} \mathrm{C}$. The chemical composition of WHTW used for investigations was as follows: $\mathrm{COD}=4900 \mathrm{mg} \mathrm{O}_{2} / \mathrm{L}, \mathrm{pH}=5.6$, conductivity $4.35 \mathrm{mS}$, Fe $78 \mathrm{mg} / \mathrm{L}$, chlorides $37 \mathrm{mg} / \mathrm{L}$, dry residues $476 \mathrm{mg} / \mathrm{L}$, total suspension $500 \mathrm{mg} / \mathrm{L}$. We decided to use reactors of well-known architecture that had been employed in our previous studies as well in many other research groups. The approach allowed for reliable comparison of the obtained results and elimination of the influence of electrode and reactor configuration on MFC work parameters [37].

After introducing WHTW to reactors, a very low voltage was generated, which resulted in production of current density not exceeding $20 \mathrm{~mA} / \mathrm{m}^{2}$ throughout 1-month observation time (Figure 2-control). These observations were different from our previous work where we used WHTW sampled from another plant where wood hydrothermal treatment conditions were different (lower temperature and much longer time of wood treatment in the basin, $\mathrm{COD}=3300 \mathrm{mg} \mathrm{O}_{2} / \mathrm{L}$ ) and then obtaining power production $318 \mathrm{~mA} / \mathrm{m}^{2}$ was possible [36]. This confirmed that wood industrial wastewater differs much between particular plants and its treatment in MFC needs optimization in each specific plant separately. Taking into account our previous findings, we mixed WHTW with municipal 
wastewater that was earlier found to stimulate development of a new microbial consortium, enabling power production and treatment of WHTW [38]. In order to investigate the influence of the external resistance on current produced in MFCs, we introduced mixed wastewaters to the reactors kept under different external resistance: $100 \Omega, 500 \Omega, 1000 \Omega$, and $2000 \Omega$ (Figure 1). Mixing wastewaters resulted in even ca. 13-fold increase in current production when compared to the control, which was coherent with our previous observations [36]. The MFC work parameters were observed for 1 month after which current density decreased, which was due to cathode fouling and is characteristic for air-cathode MFCs of the used design [39]. The lowest current density was obtained for $500 \Omega$ and the highest for $100 \Omega$, ca. $440 \mathrm{~mA} / \mathrm{m}^{2}$. Maximum power density produced was $178 \mathrm{~mW} / \mathrm{m}^{2}$ (ca. $4 \mathrm{~W} / \mathrm{m}^{3}$ ) for $\mathrm{R}=2000 \Omega$, which was comparable to the power produced from domestic wastewater $\left(1.7\right.$ to $\left.3.7 \mathrm{~W} / \mathrm{m}^{3}\right)$ in single-chamber MFC [40,41]. Maximum CE obtained here was low and did not exceed $11 \%$. Similar observation was made for the municipal wastewater-fed MFC where CE was below 12\% [42]. Low coulombic efficiencies are commonly reported for real wastewaters where fermentation and methanogenesis compete with electrogenesis [43]. Low CE means that large amount of organic matter is oxidized via fermentation or aerobic respiration alternative to electrogenesis, which was earlier reported especially for the air-cathode MFCs and is caused by oxygen leak through air cathode [44].

a
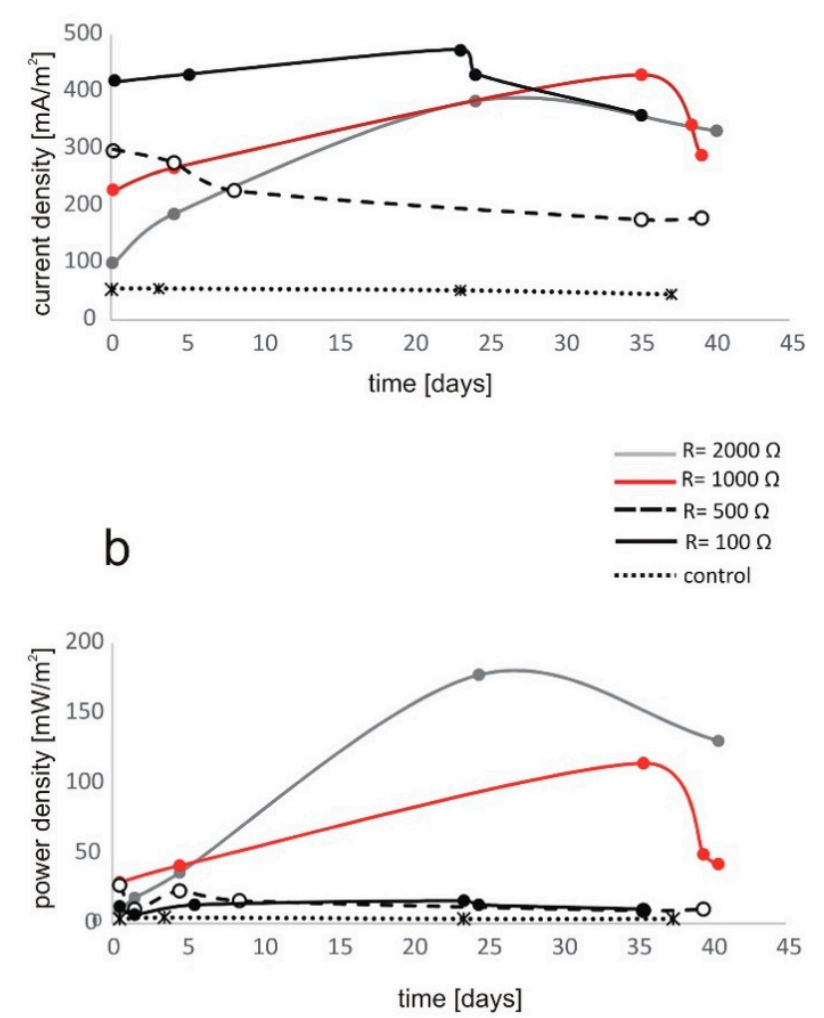

Figure 2. Maximum current density (a) and maximum power density (b) under different external resistances in MFC fed mixed wastewaters in time (control-MFC fed WHTW, R = $1000 \Omega$ ).

\subsection{Influence of External Resistance and Time on Wastewater Treatment Efficiency}

Wastewater treatment efficiency in MFCs is usually linked with the power produced in the system. Higher power produced in MFC is often identified as higher wastewater treatment efficiency. However, it is not always true as enhanced power production does not necessarily yield higher effectiveness of wastewater treatment at the same time (Table 1). Previous reports show that changing temperature from $23{ }^{\circ} \mathrm{C}$ to $30{ }^{\circ} \mathrm{C}$ allowed for ca. $20 \%$ enhancement of power produced in MFC but did not influence 
domestic wastewater treatment efficiency, which was below $30 \%$ at both temperatures [45]. An increase of oxygen flow rate to the anode chamber decreased both power production and CE in flat plate MFC but instead increased COD removal efficiency [46]. Thus, having in mind optimization of wastewater treatment in MFC we need to search conditions that, firstly, allow for enhancing treatment efficiency and, secondly, enhance power production during treatment process.

Our previous investigations showed that COD removal of undiluted wood industry wastewater in MFC is low, not reaching 40\% [36]. However, COD removal efficiency was remarkably enhanced to ca. $87 \%$ when WHTW was mixed with municipal wastewater. Thus, in the present work, COD removal was observed in MFCs fed mixed wastewaters (WHTW: municipal wastewater) under four different resistances through 33 days (Figure 3). After 15 days of MFC operation, COD did not change in MFCs under $2000 \Omega$, which indicated no wastewater treatment occurred during this time. For all other investigated resistances, wastewater treatment ran yet during first 15 days of MFC operation. The highest COD reduction during this time ( 3520 to $2160 \mathrm{mg} / \mathrm{L}$ ) was observed for the reactors under $\mathrm{R}$ $=1000 \Omega$. In all cases, treatment efficiency increased after 20 days of MFC operation, but the highest COD drop was observed after 22 days for $\mathrm{R}=1000 \Omega$ where COD decreased below $200 \mathrm{mg} / \mathrm{L}$.

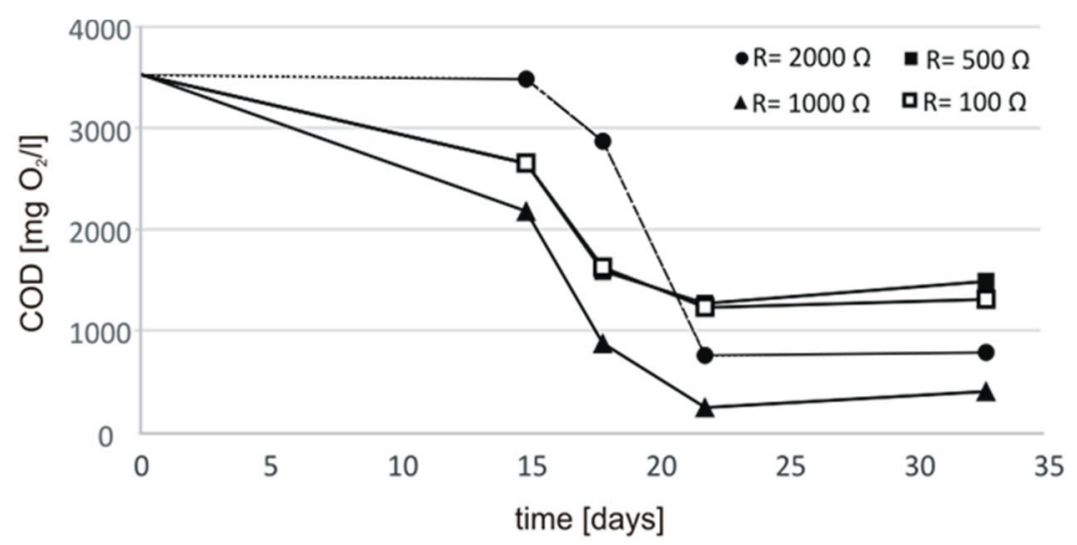

Figure 3. Changes of chemical oxygen demand (COD) in time in MFC fed mixed wastewaters under various external resistances. Analyses were made in duplicates, differences between measurements did not exceed $1 \%$.

The COD removal efficiency increased along with time during the first month of MFCs operation for all tested resistances (Figure 4). The highest $\triangle \mathrm{COD}(94 \%)$ was achieved for $\mathrm{R}=1000 \Omega$ after 22 days of MFC operation. At the same time, the lowest $\triangle$ COD (ca. 65\%) was for $R=100 \Omega$ and $500 \Omega$. Our investigations suggest that lower power production does not strictly correlate with lower wastewater treatment efficiency as though power density under $1000 \Omega$ was lower ca. $40 \%$ from power density obtained under $2000 \Omega, \Delta C O D$ was higher under $1000 \Omega$ resistance. For the highest applied resistance, wastewater treatment start-up time was also elongated in comparison to lower resistances. External resistance has been proved to be an important parameter during wastewater treatment as increasing resistance from $100 \Omega$ to $1000 \Omega$ stimulated ca. 30\% increase of COD removal efficiency. These results are different from the previous studies where the highest wastewater treatment efficiency in MFC was described for low resistance $220 \Omega$ [47]. Our investigations demonstrate that wastewater treatment in MFCs requires individual optimization in each case regarding external resistance as various wastewaters are colonized by different microorganisms that adapt differently to available substrate and resistance conditions. External resistance affects significantly anode communities what were earlier observed for two-chamber MFC where growth of methanogenic bacteria was stimulated by increasing external resistance [20]. 


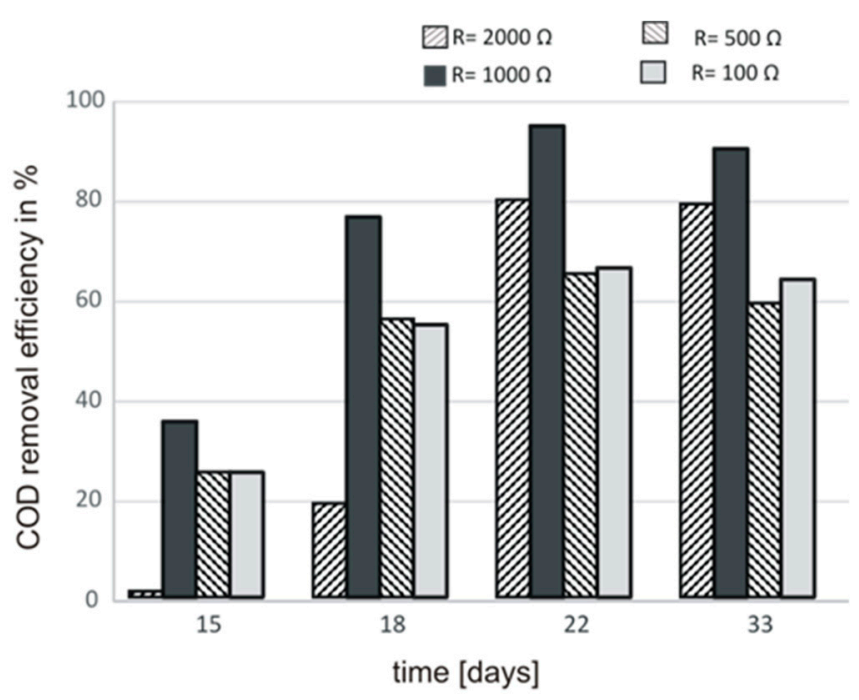

Figure 4. Influence of external resistance on COD removal efficiency of MFC fed mixed wastewaters. Analyses were made in duplicates, differences between measurements did not exceed $1 \%$.

\section{Conclusions}

External resistance is an important parameter affecting wastewater treatment efficiency. Our investigations show that peak COD removal efficiency does not always correlate with peak power produced in MFCs, as the highest wastewater treatment efficiency was obtained for external resistance under which power density was not maximized. It has been demonstrated that for the maximized wastewater treatment efficiency in MFCs, the optimum external resistance is case-specific for the wastewater to be treated. Thus, power production optimization and COD removal efficiency optimization in MFCs need to be run separately as different resistances are optimal for maximizing each of these two parameters. When COD removal efficiency optimization is needed, no general setting exists, thus the most effective external resistance must be found for a given wastewater type used.

Author Contributions: Conceptualization, R.T.-M.; methodology, R.T.-M. and M.K.; MFC measurements, COD measurements, and wastewater chemical analyses, M.K.; data curation, R.T.-M. and M.K.; writing-original draft preparation, R.T.-M.; writing—review and editing, R.T.-M.; supervision, R.T.-M.; project administration, R.T.-M.; funding acquisition, R.T.-M. All authors have read and agreed to the published version of the manuscript.

Funding: This research was funded by MINIATURA grant from The National Science Centre to Renata Toczyłowska-Mamińska (decision No. 2017/01/X/NZ9/00653).

Acknowledgments: This research was conducted in the Institute of Wood Science and Furniture, Warsaw University of Life Sciences-SGGW.

Conflicts of Interest: The authors declare no conflict of interest.

\section{References}

1. Ahn, Y.; Hatzell, M.C.; Zhang, F.; Logan, B.E. Different electrode configurations to optimize performance of multi-electrode microbial fuel cells for generating power or treating domestic wastewater. J. Power Sources 2014, 249, 440-445. [CrossRef]

2. Feng, Y.; Wang, X.; Logan, B.E.; Lee, H. Brewery wastewater treatment using air-cathode microbial fuel cells. Appl. Microbiol. Biotechnol. 2008, 78, 873-880. [CrossRef] [PubMed]

3. Mohanakrishna, G.; Mohan, S.K.; Mohan, S.V. Carbon based nanotubes and nanopowder as impregnated electrode structures for enhanced power generation: Evaluation with real field wastewater. Appl. Energy 2010, 95, 31-37. [CrossRef]

4. Aelterman, P.; Rabaey, K.; Clauwaert, P.; Verstraete, W. Microbial fuel cells for wastewater treatment. Water Sci. Technol. 2006, 54, 9-15. [CrossRef] [PubMed] 
5. Velvizhi, G.; Mohan, S.V. Biocatalyst behavior under self-induced electrogenic microenvironment in comparison with anaerobic treatment: Evaluation with pharmaceutical wastewater for multi-pollutant removal. Bioresour. Technol. 2011, 102, 10784-10793. [CrossRef] [PubMed]

6. Velasquez-Orta, S.; Head, I.; Curtis, T.; Scott, K. Factors affecting current production in microbial fuel cells using different industrial wastewaters. Bioresour. Technol. 2011, 102, 5105-5112. [CrossRef] [PubMed]

7. Rengasamy, K.; Berchmans, S. Simultaneous degradation of bad wine and electricity generation with the aid of the coexisting biocatalysts Acetobacter aceti and Gluconobacter roseus. Bioresour. Technol. 2012, 104, 388-393. [CrossRef]

8. Karthikeyan, R.; Selvam, A.; Cheng, K.Y.; Wong, J.W.-C. Influence of ionic conductivity in bioelectricity production from saline domestic sewage sludge in microbial fuel cells. Bioresour. Technol. 2016, 200, 845-852. [CrossRef]

9. Peng, X.; Tang, T.; Zhu, X.; Jia, G.; Ding, Y.; Chen, Y.; Yang, Y.; Tang, W. Remediation of acid mine drainage using microbial fuel cell based on sludge anaerobic fermentation. Environ. Technol. 2017, 38, 2400-2409. [CrossRef]

10. Haavisto, J.; Dessì, P.; Chatterjee, P.; Honkanen, M.; Noori, T.; Kokko, M.; Lakaniemi, A.-M.; Lens, P.N.; Puhakka, J.A. Effects of anode materials on electricity production from xylose and treatability of TMP wastewater in an up-flow microbial fuel cell. Chem. Eng. J. 2019, 372, 141-150. [CrossRef]

11. Li, Y.; Lu, A.; Ding, H.; Jin, S.; Yan, Y.; Wang, C.; Zen, C.; Wang, X. Cr(VI) reduction at rutile-catalyzed cathode in microbial fuel cells. Electrochem. Commun. 2009, 11, 1496-1499. [CrossRef]

12. Li, Y.; Wu, Y.; Puranik, S.; Lei, Y.; Vadas, T.; Li, B. Metals as electron acceptors in single-chamber microbial fuel cells. J. Power Sources 2014, 269, 430-439. [CrossRef]

13. Huang, L.; Liu, Y.; Yu, L.; Quan, X.; Chen, G. A new clean approach for production of cobalt dihydroxide from aqueous $\mathrm{Co}(\mathrm{II})$ using oxygen-reducing biocathode microbial fuel cells. J. Clean. Prod. 2015, 86, 441-446. [CrossRef]

14. Ichihashi, O.; Hirooka, K. Removal and recovery of phosphorus as struvite from swine wastewater using microbial fuel cell. Bioresour. Technol. 2012, 114, 303-307. [CrossRef] [PubMed]

15. Gude, V.G. Wastewater treatment in microbial fuel cells e an overview. J. Clean. Prod. 2016, 122, $287-307$. [CrossRef]

16. Integrated Pollution Prevention and Control, MInistry of Environment. 2013. Available online: http: //ippc.mos.gov.pl/ippc/ (accessed on 6 November 2019).

17. Food and Agriculture Organization. Global Forest Products Facts and Figures FAO of UN; Food and Agriculture Organization: Rome, Italy, 2016.

18. Gude, V.G. Effect of process parameters. In Microbial Electrochemical and Fuel Cells: Fundamentals and Applications; Woodhead Publishing: Kidlington, UK, 2016.

19. Costa Santos, J.B.; Silva de Barros, V.V.; Linares, J.J. The hydraulic retention time as a key parameter for the performance of a cyclically fed glycerol-based microbial fuel cell from biodiesel. J. Electrochem. Soc. 2017, 164, H3001-H3006. [CrossRef]

20. Jung, S.; Regan, J.M. Influence of External Resistance on Electrogenesis, Methanogenesis, and Anode Prokaryotic Communities in Microbial Fuel Cells. Appl. Environ. Microbiol. 2010, 77, 564-571. [CrossRef]

21. Rismani-Yazdi, H.; Christy, A.D.; Carver, S.M.; Yu, Z.; Dehority, B.A.; Tuovinen, O.H. Effect of external resistance on bacterial diversity and metabolism in cellulose-fed microbial fuel cells. Bioresour. Technol. 2011, 102, 278-283. [CrossRef]

22. Lyon, D.Y.; Buret, F.; Vogel, T.M.; Monier, J.-M. Is resistance futile? Changing external resistance does not improve microbial fuel cell performance. Bioelectrochemistry 2010, 78, 2-7. [CrossRef]

23. Katuri, K.P.; Scott, K.; Head, I.M.; Picioreanu, C.; Curtis, T.P. Microbial fuel cells meet with external resistance. Bioresour. Technol. 2011, 102, 2758-2766. [CrossRef]

24. Zhang, B.G.; Zhou, S.G.; Zhao, H.Z.; Shi, C.H.; Kong, L.C.; Sun, J.J.; Yang, Y.; Ni, J.R. Factors affecting the performance of microbial fuel cells for sulfide and vanadium (V) treatment. Bioprocess. Biosyst. Eng. 2010, 33, 187-194. [CrossRef] [PubMed]

25. Wang, H.; Fu, B.; Xi, J.; Hu, H.-Y.; Liang, P.; Huang, X.; Zhang, X. Remediation of simulated malodorous surface water by columnar air-cathode microbial fuel cells. Sci. Total. Environ. 2019, 687, 287-296. [CrossRef] [PubMed] 
26. Kim, H.; Kim, B.; Kim, J.; Lee, T.; Yu, J. Electricity generation and microbial community in microbial fuel cellusing low-pH distillery wastewater at different external resistances. J. Biotechnol. 2014, 186, 175-180. [CrossRef] [PubMed]

27. Pham, H.T.; Vu, P.H.; Nguyen, T.T.T.; Bui, H.V.T.; Tran, H.T.T.; Tran, H.M.; Nguyen, H.Q.; Kim, H.B. A laboratory-scale study of the applicability of a halophilic sediment bioelectrochemical system for in situ reclamation of water and sediment in brackish aquaculture ponds: Effects of operational conditions on performance. J. Microbiol. Biotechnol. 2019, 29, 1607-1623. [CrossRef]

28. Li, J.-T.; Zhang, S.-H.; Hua, Y.-M. Performance of denitrifying microbial fuel cell subjected to variation in $\mathrm{pH}$, COD concentration and external resistance. Water Sci. Technol. 2013, 68, 250-256. [CrossRef]

29. Logan, B.; Cheng, S.; Watson, V.; Estadt, G. Graphite Fiber Brush Anodes for Increased Power Production in Air-Cathode Microbial Fuel Cells. Environ. Sci. Technol. 2007, 41, 3341-3346. [CrossRef]

30. Cheng, S.; Liu, H.; Logan, B.E. Increased performance of single-chamber microbial fuel cells using an improved cathode structure. Electrochem. Commun. 2006, 8, 489-494. [CrossRef]

31. Karthikeyan, R.; Kumar, K.S.; Murugesan, M.; Berchmans, S.; Yegnaraman, V. Bioelectrocatalysis of Acetobacter aceti and Gluconobacter roseus for current generation. Environ. Sci. Technol. 2009, 43, 8684-8689. [CrossRef]

32. Woods, J.; Mellon, M. Thiocyanate Method for Iron: A Spectrophotometric Study. Ind. Eng. Chem. Anal. Ed. 1941, 13, 551-554. [CrossRef]

33. PN-72/C-04559. Water and Waste Water Tests for Suspended Matters-Determination of Total, Mineral and Volatile Suspended Matters by Gravimetric Method (in Polish); Polish Committee for Standarization: Warsaw, Poland, 1973.

34. PN-C-04541. Water and Sewage-Determination of the Dry Residue Residue on Ignition Loss on Ignition and Solute Substances Mineral Solute Substances and Volatile Solute Substances (in Polish); Polish Committee for Standarization: Warsaw, Poland, 1978.

35. Dedkov, Y.M.; Elizarova, O.V.; Kel'Ina, S.Y. Dichromate method for the determination of chemical oxygen demand. J. Anal. Chem. 2000, 55, 777-781. [CrossRef]

36. Toczyłowska-Mamińska, R.; Szymona, K.; Kloch, M. Bioelectricity production from wood hydrothermal-treatment wastewater: Enhanced power generation in MFC-fed mixed wastewaters. Sci. Total. Environ. 2018, 634, 586-594. [CrossRef] [PubMed]

37. Yang, W.; Kim, K.-Y.; Saikaly, P.E.; Logan, B.E. The impact of new cathode materials relative to baseline performance of microbial fuel cells all with the same architecture and solution chemistry. Energy Environ. Sci. 2017, 10, 1025-1033. [CrossRef]

38. Angosto, J.M.; Fernández-López, J.A.; Godinez, C. Brewery and liquid manure wastewaters as potential feedstocks for microbial fuel cells: A performance study. Environ. Technol. 2015, 36, 68078. [CrossRef] [PubMed]

39. Yang, W.; Son, M.; Xiong, B.; Kumar, M.; Bucs, S.; Vrouwenvelder, J.S.; Logan, B.E. Effective biofouling control using periodic $\mathrm{H} 2 \mathrm{O} 2$ cleaning with $\mathrm{CuO}$ modified and plain spacer. ACS Sustain. Chem. Eng. 2019, 7, 9582-9587. [CrossRef]

40. Liu, H.; Ramnarayanan, R.; Logan, B.E. Production of Electricity during Wastewater Treatment Using a Single Chamber Microbial Fuel Cell. Environ. Sci. Technol. 2004, 38, 2281-2285. [CrossRef]

41. Liu, H.; Logan, B.E. Electricity Generation Using an Air-Cathode Single Chamber Microbial Fuel Cell in the Presence and Absence of a Proton Exchange Membrane. Environ. Sci. Technol. 2004, 38, 4040-4046. [CrossRef]

42. Ketep, S.F.; Fourest, E.; Bergel, A. Experimental and theoretical characterization of microbial bioanodes formed in pulp and paper mill effluent in electrochemically controlled conditions. Bioresour. Technol. 2013, 149, 117-125. [CrossRef]

43. Durruty, I.; Bonanni, P.S.; Gonzalez, J.F.; Busalmen, J.P. Evaluation of potato-processing wastewater treatment in a microbial fuel cell. Bioresour. Technol. 2012, 105, 81-87. [CrossRef]

44. Huang, L.; Cheng, S.; Rezaei, F.; Logan, B.E. Reducing organic loads in wastewater effluents from paper recycling plants using microbial fuel cells. Environ. Technol. 2009, 30, 499-504. [CrossRef]

45. Ahn, Y.; Logan, B.E. Effectiveness of domestic wastewater treatment using microbial fuel cells at ambient and mesophilic temperatures. Bioresour. Technol. 2010, 101, 469-475. [CrossRef] 
46. Min, B.; Logan, B.E. Continuous Electricity Generation from Domestic Wastewater and Organic Substrates in a Flat Plate Microbial Fuel Cell. Environ. Sci. Technol. 2004, 38, 5809-5814. [CrossRef] [PubMed]

47. Corbella, C.; Puigagut, J. Improving domestic wastewater treatment efficiency with constructed wetland microbial fuel cells: Influence of anode material and external resistance. Sci. Total. Environ. 2018, 2018, 1406-1414. [CrossRef] [PubMed]

C 2020 by the authors. Licensee MDPI, Basel, Switzerland. This article is an open access article distributed under the terms and conditions of the Creative Commons Attribution (CC BY) license (http://creativecommons.org/licenses/by/4.0/). 